\title{
Synthesis and Characterization of some Hippurato Rare Earth Metal Complexes
}

\author{
M.S. Refat ${ }^{*}$, S.M. Teleb ${ }^{\dagger}$, S.A. Sadeek ${ }^{\dagger}$, H.M. Khater ${ }^{\star}$, and S.M. El-Megharbel ${ }^{\dagger}$ \\ Chemistry Department. Faculty of Edication. Port Said Stez Canal University: Egrpt \\ ${ }^{\dagger}$ Chemisty Deparment, Faculty of Science, Zagarg Lniversin? Zagazig, Egypt \\ (2005. 3.24 섭수)

\section{Synthesis and Characterization of some Hippurato Rare Earth Metal Complexes}

\author{
M.S. Refat ${ }^{*}$, S.M. Teleb ${ }^{\dagger}$, S.A. Sadeek ${ }^{\dagger}$, H.M. Khater ${ }^{\star}$, and S.M. El-Megharbel ${ }^{\dagger}$

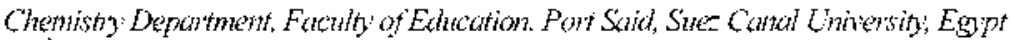 \\ ${ }^{\dagger}$ Chemishy: Depatment, Faculty of Science. Zaguzig Lhtiversib: Zagazig, Egpt \\ (Received March 24, 2005)
}

요 약. 희토류 원소늘온 마뇨산 $(\mathrm{HL})$ 과, $\mathrm{ML}_{3} \cdot n \mathrm{H}_{2} \mathrm{O}(\mathrm{M}=\mathrm{La}(\mathrm{IJJ}), \mathrm{n}=4 ; \mathrm{M}=\mathrm{Ce}(\mathrm{JII}), \mathrm{n}=7 ; \mathrm{M}=\mathrm{Sm}(\mathrm{IIJ}), \mathrm{n}=8 ; \mathrm{HL}=$ hippuric acid) 라는 인반식으로 표현될 수 있는 화합물늘을 생성한다. 생성된 고체 화합물늘의 특성이 원소분석, IR, 'H NMR, 전자 스페늩라. 그러고 연중량 분석을 통해 조사되었다. 리간드와 금속 이혼늘간의 비위 형태도 결정되있다.

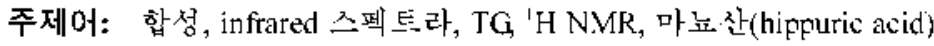

ABSTRACT. Rare earth elements form complexes with hippuric acid with the general formula, $\mathrm{ML}_{3} ; \mathrm{H}_{2} \mathrm{OMM}=\mathrm{La}, \mathrm{Ce}$ and $\operatorname{Sin}(\mathrm{IIT}$ ) where $\mathrm{n}=4,7$ and 8 respectively, $\mathrm{HL}=$ hippuric acid). The solid complexes formed were chatacterized through their elemental analysis, IR. 'HNMR and electronic spectral as well as thermogravimetric analysis. The mode of coordination between the ligand and the metal ions were detemined.

Keywords: Synthesis, Infiared Spectra, TG, 'HNMR, Hippuric Acid

\section{INTRODLCTION}

The study of the reaction between metals and hippuric acid, 4-amino hippuric acid, nucleoside or related base type is a topic of increasing interest due to their presence in biological system. It is produced in the renal metabolism of P-amino benzoic and it is also involved in sulfate transport in human neutrophils. ${ }^{1-5}$ From the chemical studies for the hippuric acid derivatives such as 4-amino hippuric acid indicate that the presence of an $\mathrm{NH}_{2}$ group on the phenyl ring could, in principle, be a potential donor group in metal coordination. ${ }^{+8}$ In these studies the ligand is reported to act as an $\mathrm{N}, \mathrm{O}$ bridging ligand besides its normal monodentate behavior through the carboxylate oxygen.

IIippurates of $\mathrm{Mn}(\mathrm{II}), \mathrm{Cd}(\mathrm{II}), \Lambda \mathrm{g}(\mathrm{I}), \mathrm{Zn}(\mathrm{II})$ and IIg(II) were isolated from solutions as crystal solids. ${ }^{8-12}$ The infrared spectra for all studied hippurate complexes and $\mathrm{X}$-ray crystal structure of the $\mathrm{Cd}(\mathrm{II})$ hippurate complex ${ }^{\delta}$ indicate that metal hippurate coordination involves only the carboxylate group via the two oxygen atoms as a chelating ligand. 
<smiles>O=C(O)CNC(=O)c1ccccc1</smiles>

(I)

The aim of this work is to synthesize and examine systematically, in the solid state, the new hippurate complexes formed on the reaction of lanthanum(III) nitrate and cerium(III), Samarium(III) chlorides with hippuric acid shown in (I) in alkaline media. The products complexes were characterized by their elemental analysis, IR, 'HNMR and clectronic spectrat as well as thermo gravimetric analysis to elucidate the coordination properties of hippuric acid with these metal jons.

\section{EXPERIMENTAL}

All of the reagent employed in this investigation was of analytical grade. The white solid complex [La(hip) $] \cdot 4 \mathrm{I}_{2} \mathrm{O}$ was prepared by adding lanthanum(III) nitrate hexalyydrate $(0.866 \mathrm{~g}, 2 \mathrm{mmole})$ in $10 \mathrm{ml}$ bidistilled water dropwisly to a stirred $\mathrm{mix}$ ture ol hippuric acid ( $1.074 \mathrm{~g}, 6 \mathrm{mmol})$ in $5 \mathrm{ml}$ ethanol and sodium hydroxide $(0.240 \mathrm{~g}, 6 \mathrm{mmol})$ in $50 \mathrm{ml}$ bidistilled water. The reaction mixture was heated to about $60^{\circ} \mathrm{C}$. for about $3 \mathrm{~h}$., the resulting precipitate was filtered, washed several times with hot water, and dried over phosphorous pentoxide. The hippurate complexes $\left[\mathrm{Ce}(\text { hip })_{2}\right] \cdot 7 \mathrm{H}_{2} \mathrm{O}$ and $\left[\mathrm{Sm}(\mathrm{hip})_{3}\right] \cdot 8 \mathrm{II}_{2} \mathrm{O}$ were prepared in a similar way to that described above by the reaction of $\mathrm{CeCl}_{3} \cdot 7 \mathrm{II}_{2} \mathrm{O}$ and $\mathrm{SmCl}_{1} \cdot 6 \mathrm{H}_{2} \mathrm{O}$ with hippuric acid in a molar ratio of $1: 3$, respectively.

Filemental $\mathrm{C}, \mathrm{H}, \mathrm{N}$ analysis were carried out on a
Perkin Elmer CHN 2400. Lanthanum, cerium and samarium contents were deternined gravimetrically by transforming the product into the corresponding oxides. The obtained analytical data are summarized in Table 1. Infrared spectra $\left(4000-400 \mathrm{~cm}{ }^{~}\right)$ were recorded as $\mathrm{KBr}$ pellets on a Gensis II FT IR spectrometer and the electronic spectra were registed on a Shimadzu UV -spectrophotometer model 1601 PC in the region of $700-200 \mathrm{~nm}$. 'HNMR spectra were recorded on a Varian Gemini $200 \mathrm{MIIZ}$, at room temperature.

Themegravimetric (TG) was carried out under $\mathrm{N}_{2}$-atmosphere using detectors model Shimadzu TGA-50 H.

\section{RESULTS AND DISCUSSION}

Hippuric acid reacts with $\mathrm{L}$ a (III) nitrate and $\mathrm{Ce}$ (1I1), Sin (III) chlorides in alkaline aqueous media at about $60^{\circ} \mathrm{C}$ to form the obtained solid hippurate complexes formulated as [La(hip), ] $4 \mathrm{H}_{2} \mathrm{O},\left[\mathrm{Ce}(\mathrm{hip})_{3}\right]$. $7 \mathrm{I}_{2} \mathrm{O}$ and $\left[\mathrm{Sm}(\mathrm{hip})_{3}\right] \cdot 8 \mathrm{H}_{2} \mathrm{O}$, respectively. The infrared spectra of hippuric acid and its complexes are given in Fig. 1, and their band assignments are given in Table 2. In the inlrared spectra of the La(III), Ce(III) and $\mathrm{Sm}$ (III) complexes some bands disappear at 1758 and $1750 \mathrm{~cm}^{-1}$, arising from the free carboxylic acid $(-\mathrm{COOH})$ group as shown in the spectrum of hippuric acid. This indicates that the hydrogen ion in the hippuric acid molecule is substituted by the metal ions. However, the IR spectra of the prepared hippurates show strong absorption bands in the region of $1578-1537 \mathrm{~cm}^{-1}$ due to the asymmetrical vibration of the carboxylate anion, $v_{\mathrm{its}}\left(\mathrm{COO}^{-}\right)$. The corresponding symmetric vibration $v_{s}\left(\mathrm{COO}^{-}\right)$is observed in the region $1426-1405 \mathrm{~cm}^{-1}$. The shift of the absorption band of $v_{\text {an }}\left(\mathrm{COO}^{-}\right)$to lower frequencies, suggests that carboxylate anion

Tohle 1. Analytical data

\begin{tabular}{|c|c|c|c|c|c|c|c|c|}
\hline \multirow{2}{*}{ Compounds } & \multicolumn{2}{|c|}{$C \%$} & \multicolumn{2}{|c|}{$\mathrm{I} 1 \%$} & \multicolumn{2}{|c|}{$N \%$} & \multicolumn{2}{|c|}{$M^{3 \cdot 0 / 0}$} \\
\hline & Found & Cále. & Found & Calc: & Found & Calc. & Found & Calc: \\
\hline$\left.\left[\mathrm{I} . \mathrm{a}(\mathrm{hip})_{3}\right] \cdot 4\right] \mathrm{I}_{2} \mathrm{O}$ & 43.37 & 43.48 & 4.26 & 4.29 & 5.60 & 5.63 & 18.59 & 18.65 \\
\hline$\left.\left[\mathrm{Ce}(\text { hip) })_{3}\right] \cdot 7\right]_{2}(\mathrm{O}$ & 51.42 & 51.59 & 4.79 & 4.74 & 5.19 & 5.24 & 17.49 & 17.51 \\
\hline$[\mathrm{Sm}$ (hip) $] \cdot 8] \mathrm{I}_{2}(\mathrm{O})$ & 39.08 & 39.13 & 4.79 & 4.83 & 5.03 & 5.07 & 18.08 & 18.11 \\
\hline
\end{tabular}




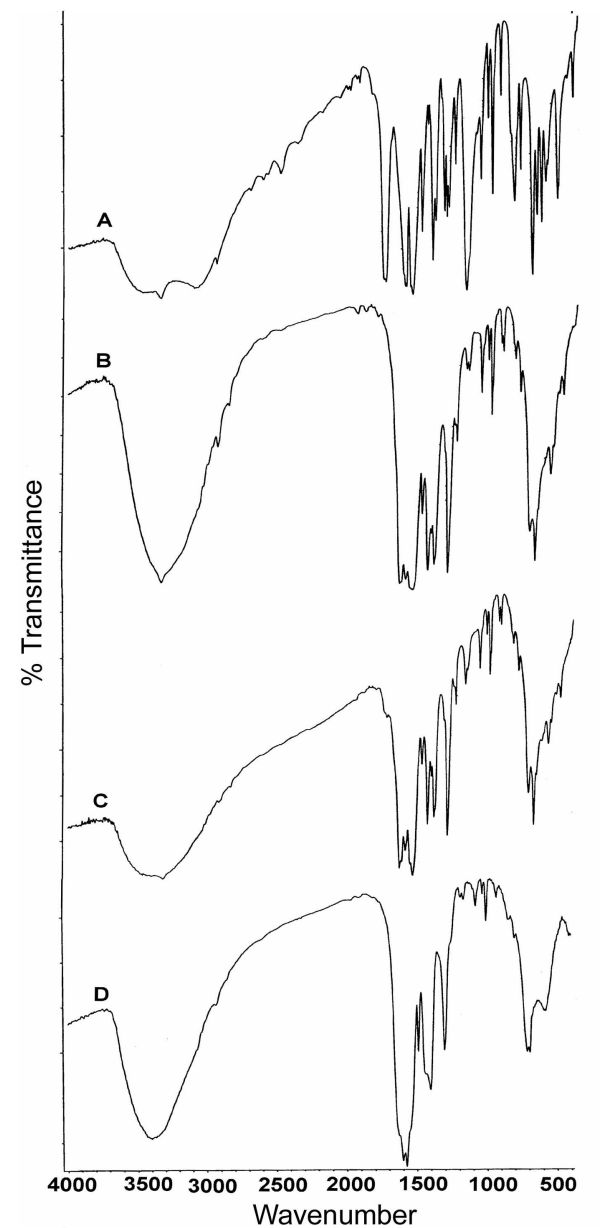

Fig. 1. Infrared spectra of: ( $\mathrm{A})$ : ] lippuric acid, (B): [1 a(lip) $]$

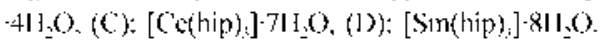

in the complexes under study behaves as a chelating ligand ( $^{3}$ (Table 2). The coordination of the metal ions via oxygens of the carboxylate is confirmed by observing $\mathrm{M}-\mathrm{O}$ band stretching vibrations, $\mathrm{V}(\mathrm{M}-\mathrm{O})$ at 538 and $494 \mathrm{~cm}^{-1}$ for La (III), at 588,530 and $499 \mathrm{~cm}^{-1}$ for $\mathrm{Ce}$ (III) and at 588 and $446 \mathrm{~cm}^{-1}$ for Sm (III) complex. These bands are not observed in the spectrum of hippuric acid. A new broad band is also observed in the complexes spectra in the region $3400-3470 \mathrm{~cm}^{1}$ duc to the vibration $v(\mathrm{OH})$ of lattice water in the hydrated complexes. The infrared spectra of $\mathrm{M}(\mathrm{IIl})$ hippurates display a group of bands due to $\mathrm{N}-1 \mathrm{I}$ vibrations at $3365-3070 \mathrm{~cm}^{-1}$ and $1650-1598 \mathrm{~cm}^{-1}$. This last band exhibits both bend- ing motion, $\delta(\mathrm{N}-\mathrm{J})$ and ring vibrational character. The assignment of those bands agrees quite well with those for related complexes containing typical hippurate ligands. ${ }^{813+16}$ The complexes were also investigated by ${ }^{1} H N M R$ in IMSO-do as a solvent Fig. 2, where the data obtained are in agreement with the proposed coordination through the carboxylic group (disappearance of the $H(1)$ signal) in a symmetrical geometry and the peaks characteristic lor water molecules were observed around 03.52 ppm. The 'IINMR data lor free hippuric acid: $\delta 12.5$ (II, II(1), COOII), 8.84, 8.80 [II, JI(3)], 7.91 [2H, $\mathrm{II}(6)], 7.53[3 \mathrm{II}, \mathrm{H}(7.8)], 3.97,3.94[2 \mathrm{H}, \mathrm{II}(2)]$, for [a(bip)] ${ }^{4} 4 \mathrm{I}_{2} \mathrm{O}: 8 \mathrm{8} 8.34$ [1H, II(3)], 7.88 [2H, H(6)], $7.45[3 \mathrm{H}, \mathrm{H}(7.8)], 3.85[2 \mathrm{H}, \mathrm{H}(2)], 3.25,3.17[\mathrm{H}$, $\left.\left(\mathrm{H}_{2} \mathrm{O}\right)\right]$, for $\left[\mathrm{Cc}(\mathrm{hip})_{3}\right] \cdot 7 \mathrm{H}_{3} \mathrm{O}: \delta 9.24[1 \mathrm{H}, \mathrm{H}(3)], 7.96$ [2H, H(6)], $7.51[3 \mathrm{H}, \mathrm{H}(7.8)], 4.93[2 \mathrm{H}, \mathrm{H}(2)], 3.76$ $\left[\mathrm{H},\left(\mathrm{H}_{2} \mathrm{O}\right)\right.$ and for $\left[\mathrm{Sm}-(\text { hip) })_{3}\right] \cdot 8 \mathrm{H}_{2} \mathrm{O}: \delta 8.8(1 \mathrm{H}$, $\mathrm{H}(3), 7.88(2 \mathrm{H}, \mathrm{H}(6), 7.503 \mathrm{H}, \mathrm{H}(7.8)], 3.94[2 \mathrm{H}$, $\mathrm{H}(2)], 3.31\left[\mathrm{H},\left(\mathrm{H}_{2} \mathrm{O}\right)\right]$. The aromatic signals $\mathrm{H}(6)$, $H(7)$ and $H(8)$ nearly do not shift significantly, thus showing that the magnetic environment of the aromatic ring has not changed significantly with coordination.

To make sure about the proposed structure for our hippurate complexes the electronic spectra were carried out in dimelhyl sulfoxide, which absorbed around $260 \mathrm{~nm}$. Fig. 3. The absorption spectra of $\mathrm{M}(\mathrm{III})$ hippurate are compared with the absorption maxima of hippuric acid, there are evident that the increasing in the absorbance (hyperchromic effect) clasitied in all of the three mentioned hippuric acid complexes attributed to the complexation behavjour of hippuric acid towards metal ions.

Thermogravimetric (TG) was carried out under a $\mathrm{N}_{2}$ atmosphere, Fig. 4. Decomposition mechanisms have been shown in Table 3. Decomposition of the complexes starts at difterent temperatures and cxhibits two degradation stages. The hydrated complexes of Ce(III) and Sm(III) lose upon heating some water molecules in one step within the temperature range of $50-150$ " $\mathrm{C}$ with an accompanying a weight loss of $9.12 \%$ and $6.22 \%$, corresponding with the loss of tour and three water molecules in agreement with the theoretical values of $9.00 \%$ and $6.52 \%$, respec- 
Table 2. Infraned frequencies: ${ }^{2}\left(\mathrm{~cm}^{-1}\right)$ and tentative assignments for hippuric acid and of its Lat (II), Cer(II) and Sm(TI) complexes

\begin{tabular}{|c|c|c|c|c|}
\hline I Iippuric & [Lat hip)] $]+\mathrm{II}_{2} \mathrm{O}$ & [Cet hip) $] 7 \mathrm{I}_{2} \mathrm{O}$ & [Sn(hip):] $8 \mathrm{II} \mathrm{O}$ & Assignnents \\
\hline & $3+00 \mathrm{mbr}$ & $\begin{array}{l}3470 w \\
3+17 W\end{array}$ & $3423 \mathrm{mbr}$ & Y(OIT) $) \mathrm{HIO}$ \\
\hline $\begin{array}{l}33+4 w \\
3100 v w \\
307+v w\end{array}$ & $\begin{array}{l}3328 \mathrm{mb} \\
3260 \mathrm{w} \\
3076 \mathrm{vw}\end{array}$ & $\begin{array}{l}3328 \mathrm{w} \\
3066 \mathrm{vw}\end{array}$ & $\begin{array}{l}3365 \mathrm{w} \\
3070 \mathrm{w}\end{array}$ & $\psi(\mathrm{NII})$ \\
\hline $\begin{array}{l}2940 \mathrm{w} \\
2699 \mathrm{w} \\
2605 \mathrm{w} \\
2480 \mathrm{~m}\end{array}$ & $\begin{array}{l}2935 \mathrm{w} \\
2862 \mathrm{vw}\end{array}$ & $\begin{array}{l}2930 \mathrm{vu} \\
2846 \mathrm{vw}\end{array}$ & $\begin{array}{l}2950 \mathrm{Nw} \\
2860 \mathrm{Nw}\end{array}$ & $\psi(\mathrm{CII})$ \\
\hline $\begin{array}{l}1758 \mathrm{sh} \\
1750 \mathrm{ss}\end{array}$ & & & & $v(C=0) ;(C O O H)$ \\
\hline $\begin{array}{l}1630 \mathrm{sh} \\
1615 \mathrm{ss} \\
1562 \mathrm{ss}\end{array}$ & $\begin{array}{l}1650 \mathrm{~ms} \\
1636 \mathrm{~ms} \\
1610 \mathrm{~m}\end{array}$ & $\begin{array}{l}1646 \mathrm{~s} \\
1640 \mathrm{sh} \\
1610 \mathrm{~s}\end{array}$ & $\begin{array}{l}1610 \mathrm{sh} \\
1598 \mathrm{vs}\end{array}$ & $\begin{array}{l}\delta(\mathrm{NH}) \\
\delta\left(\mathrm{H}_{2} \mathrm{O}\right)\end{array}$ \\
\hline & $\begin{array}{l}1572 \mathrm{~m} \\
1552 \mathrm{~m}\end{array}$ & $1537 \mathrm{~s}$ & $1553 \mathrm{~s}$ & $v_{12}\left(\mathrm{COO}^{\circ}\right)$ \\
\hline $\begin{array}{l}1+94 \mathrm{~s} \\
1+47 \mathrm{~m}\end{array}$ & $\begin{array}{l}1489 \mathrm{~s} \\
1452 \mathrm{vs}\end{array}$ & $\begin{array}{l}1489 \mathrm{~s} \\
1458 \mathrm{vs}\end{array}$ & $\begin{array}{l}1495 \mathrm{ws} \\
1442 \mathrm{sh}\end{array}$ & $\mathrm{C}-\mathrm{H}$ deformation $-\mathrm{CH}_{2}$ \\
\hline $\begin{array}{l}1420 \mathrm{~s} \\
1+00 \mathrm{~ms}\end{array}$ & $\begin{array}{l}1426 \mathrm{w} \\
1405 \mathrm{~s}\end{array}$ & $\begin{array}{l}1426 \mathrm{~m} \\
1+10 \mathrm{vs}\end{array}$ & $1406 \mathrm{~m}$ & $r_{s}\left(\mathrm{COO}^{-}\right)$ \\
\hline $\begin{array}{l}1342 \mathrm{~s} \\
1427 \mathrm{~s} \\
1300 \mathrm{~s}\end{array}$ & 1311 ws & 1306 vs & $1306 \mathrm{vs}$ & $\hat{\theta}\left(\mathrm{CH} \mathrm{I}_{i}\right)$ \\
\hline$\overline{1259 \mathrm{~s}}$ & $1253 \mathrm{~m}$ & $1253 \mathrm{~s}$ & $1255 \mathrm{sh}$ & $\gamma(C-C)$ \\
\hline $1180 \mathrm{ws}$ & $\begin{array}{l}1185 \mathrm{~m} \\
1175 \mathrm{~m}\end{array}$ & $1180 \mathrm{~s}$ & $\begin{array}{l}1180 w \\
1165 w\end{array}$ & $\hat{\delta}(\mathrm{CI} I)$, in-plane bend \\
\hline $\begin{array}{l}1080 \mathrm{~s} \\
1033 \mathrm{~s} \\
1007 \mathrm{ss}\end{array}$ & $\begin{array}{l}1080 \mathrm{~s} \\
1033 \mathrm{~ms} \\
1077 \mathrm{vs}\end{array}$ & $\begin{array}{l}1075 \mathrm{~s} \\
1033 \mathrm{~s} \\
1012 \mathrm{~s}\end{array}$ & $\begin{array}{l}1086 \mathrm{~m} \\
1023 \mathrm{~m}\end{array}$ & $\hat{\delta}_{i}\left(\mathrm{CHI}_{i}\right)$ \\
\hline $\begin{array}{l}949 \mathrm{~s} \\
855 \mathrm{rs} \\
803 \mathrm{rs}\end{array}$ & $\begin{array}{l}976 \mathrm{rw} \\
939 \mathrm{w} \\
923 \mathrm{~m} \\
839 \mathrm{~m} \\
798 \mathrm{~m}\end{array}$ & $\begin{array}{l}939 \mathrm{~m} \\
923 \mathrm{~s} \\
839 \mathrm{~m} \\
803 \mathrm{~m}\end{array}$ & $\begin{array}{l}997 \mathrm{~ms} \\
942 \mathrm{w} \\
840 \mathrm{w} \\
808 \mathrm{w}\end{array}$ & $V(C-C)$ \\
\hline $729 \mathrm{ss}$ & $729 \mathrm{~m}$ & $729 \mathrm{~ms}$ & $714 \mathrm{~ms}$ & $8\left(\mathrm{COO}^{-}\right)$ \\
\hline $\begin{array}{l}698 \mathrm{~s} \\
667 \mathrm{~s} \\
625 \mathrm{~s} \\
551 \mathrm{~s} \\
473 \mathrm{w} \\
431 \mathrm{~m}\end{array}$ & $\begin{array}{l}689 \mathrm{vs} \\
635 \mathrm{sh} \\
583 \mathrm{~ms} \\
494 \mathrm{~m}\end{array}$ & $\begin{array}{l}693 \mathrm{~s} \\
635 \mathrm{sh} \\
588 \mathrm{~m} \\
562 \mathrm{sw} \\
530 \mathrm{wm} \\
499 \mathrm{~m}\end{array}$ & $\begin{array}{l}693 \mathrm{~ms} \\
588 \mathrm{~m} \\
46 \mathrm{sw}\end{array}$ & $v(\mathrm{M}-\mathrm{O})+$ Ring def. \\
\hline
\end{tabular}

(a): s=strong, w=weak, in=medium, sh=shoulder, varer, br=broad.

(b): $\psi$, stretching: $\delta$ and $\partial_{s}$ correspond to bending and rocking motions, respectively.

tively, while the complex [La(hip) $)_{3} \cdot 4 \mathrm{H}_{2} \mathrm{O}$ is dehydrated completely in one step at a maximum temperature of $89^{\circ} \mathrm{C}$. The relatively low value of temperature of this step may indicate that these water molecules undergoes less II-bonding with hippurate anion. The trihydrated $\mathrm{Ce}(\mathrm{III})$ hippurate and penta hydrated Sm(III) complex are simultaneously dehydrated and decomposed to the corresponding oxide at the 
A:

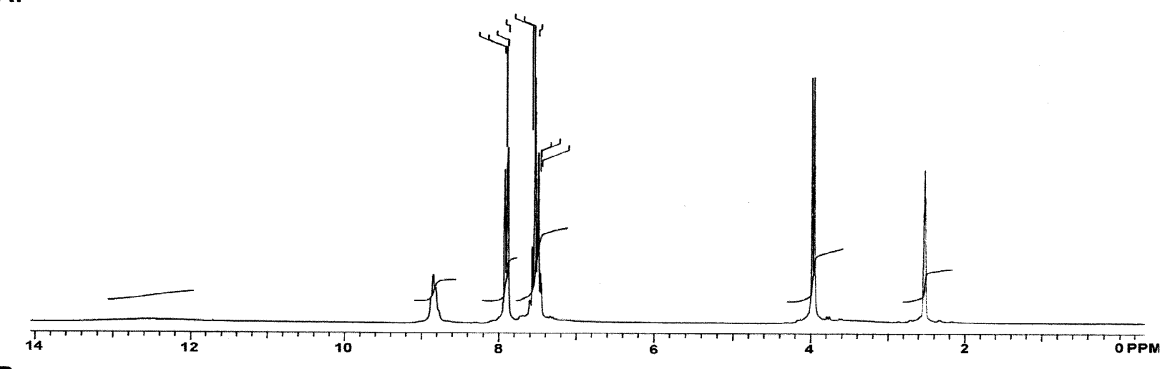

B:

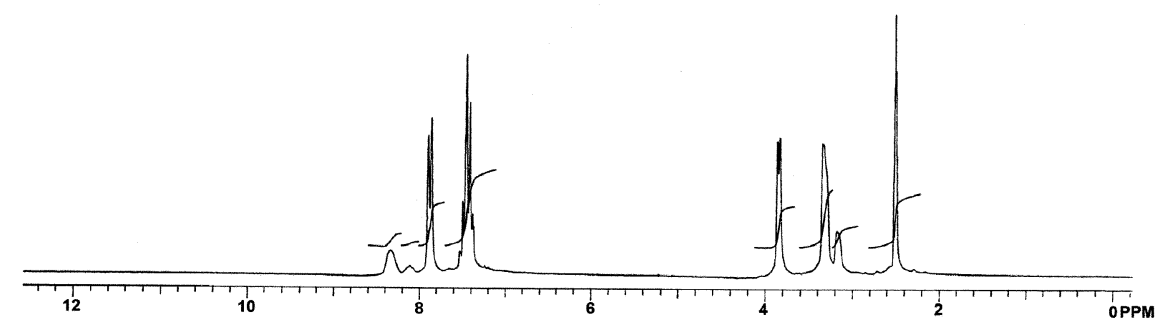

C:

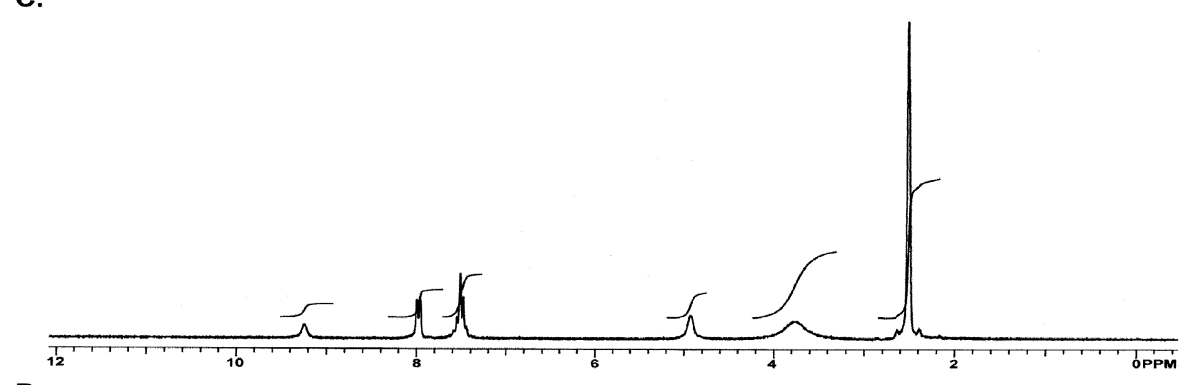

D:

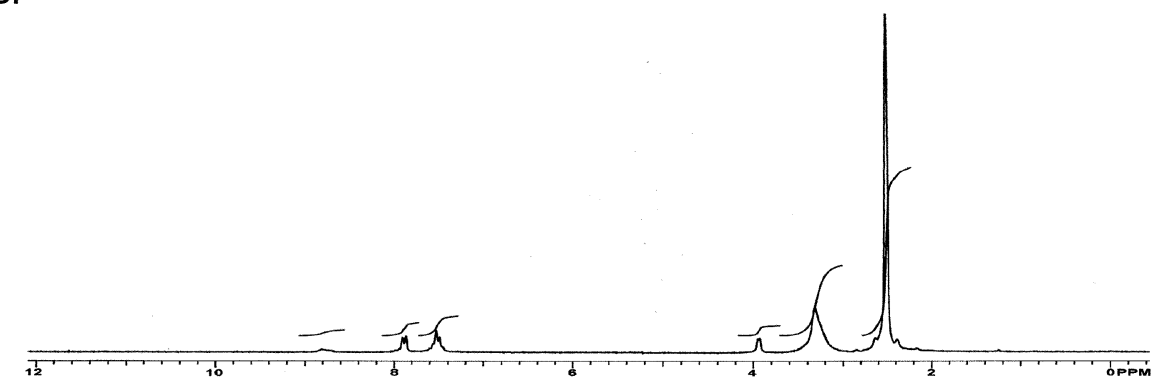

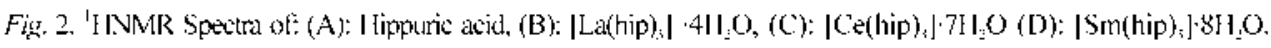

lemperature range $150-800^{\circ} \mathrm{C}$ with intermediale formation of very unstable products ${ }^{1 \hat{3}}$ which were not identified. The dehydrated La(III) complex is stable within the temperature range of $110-250^{\circ} \mathrm{C}$ and then decompose to oxide, $\mathrm{La}_{2} \mathrm{O}_{3}$ within the temperature range of $250-800^{\circ} \mathrm{C}$. The proposed structural formula on the basis of the results discussed in our paper located as follows:

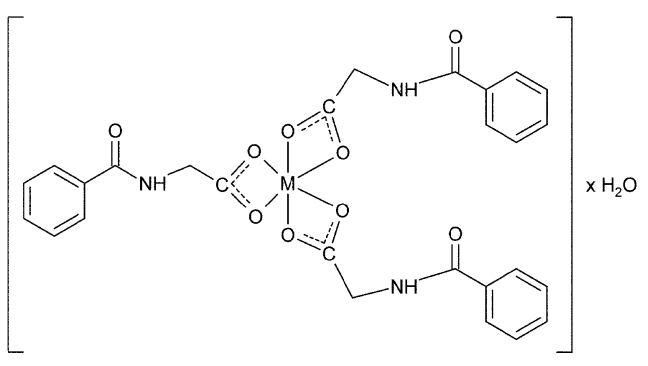

$(\mathrm{M}=\mathrm{La}, \mathrm{Ce}$ and $\mathrm{Sm}$ where $\mathrm{x}=4,7$ and 8, respectively $)$

2005 lod 49.80 .3 

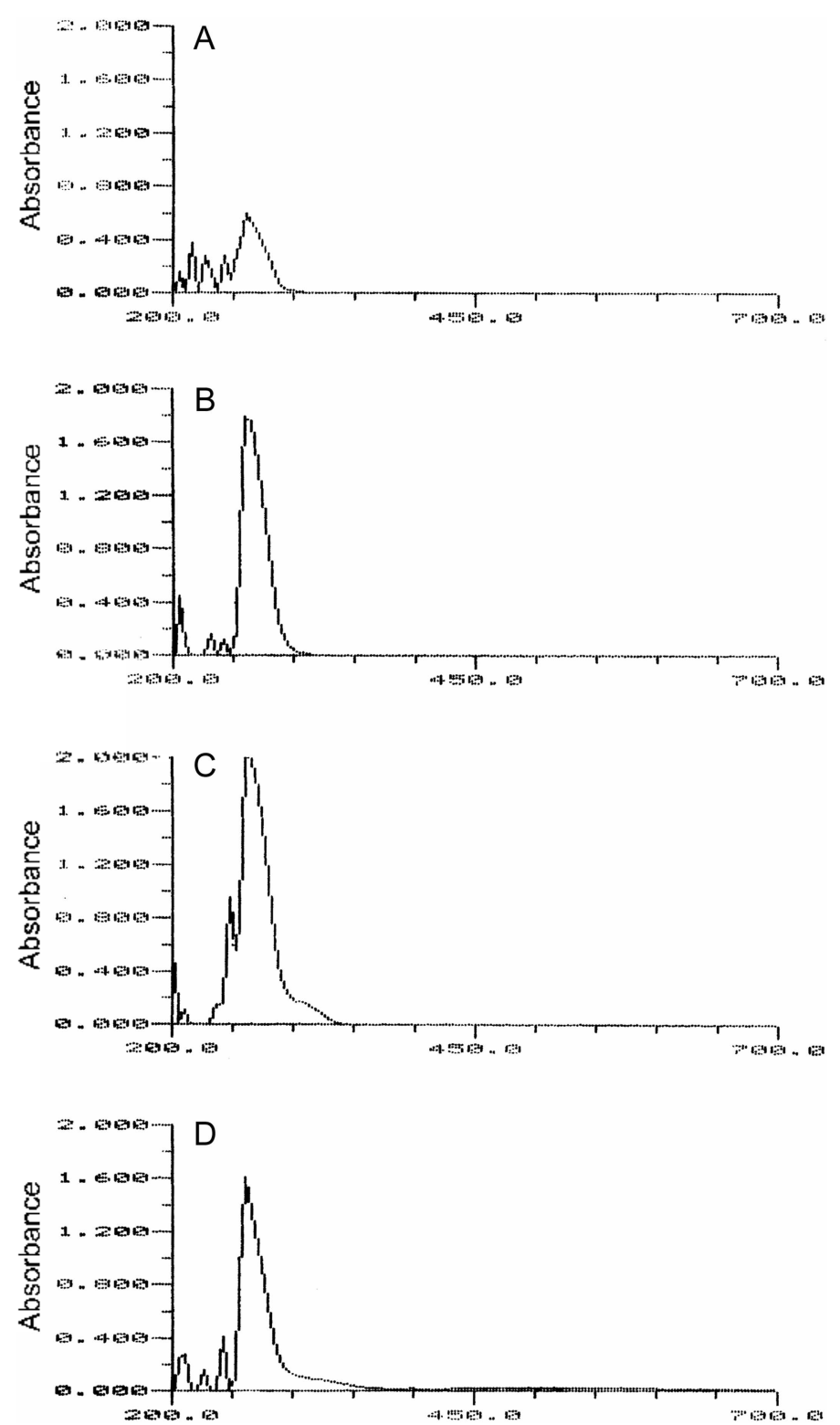

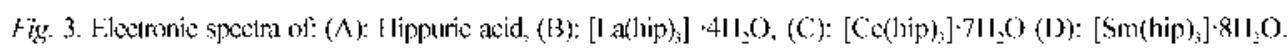

The infrared spectra of the linal products Fig. 5 , show the absence of all bands associated with the hippurate anion and water molceules and instead the characteristic spectra for oxides are appeared. According to the above discussion, the mechanisms proposed for the thermal decomposition ol hippurato complexes are summarized as follow: i) $[\mathrm{La}$ (hip): $] \cdot 4 \mathrm{II}_{2} \mathrm{O} \stackrel{\mathrm{sac}}{\longrightarrow} \mathrm{La}($ hip $) ; 44 \mathrm{I}_{2} \mathrm{O}$

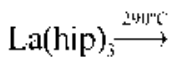

$$
\begin{aligned}
& 10 \mathrm{C}_{2} \mathrm{H}_{2}+\mathrm{NH}_{3}+5 \mathrm{CO}+\mathrm{H}_{2} \mathrm{O}+2 \mathrm{NO}+2 \mathrm{C}+\mathrm{LaO}_{15}
\end{aligned}
$$

ii) $\left[\mathrm{Ce}(\mathrm{hip})_{3} \cdot 7 \mathrm{II}_{2} \mathrm{O} \stackrel{119 \%}{\longrightarrow}\left[\mathrm{Ce}(\text { hip })_{3}\right]-3 \mathrm{H}_{2} \mathrm{O}+4 \mathrm{H}_{2} \mathrm{O}\right.$

$$
\left[\mathrm{Ce}(\text { hip })_{1}\right] \cdot 3 \mathrm{II}_{2} \mathrm{O} \stackrel{4: 33^{\circ} \mathrm{C}}{\longrightarrow}
$$



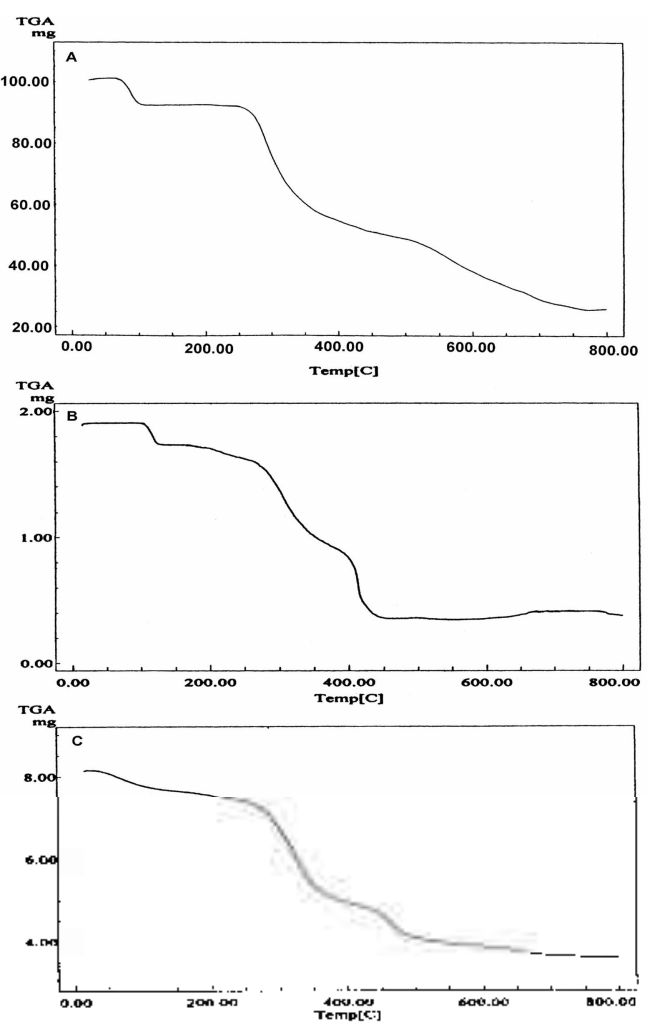

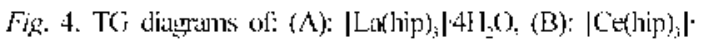
$711,0,(\mathrm{C}):$ : Sm(hip), ] 811.0 .

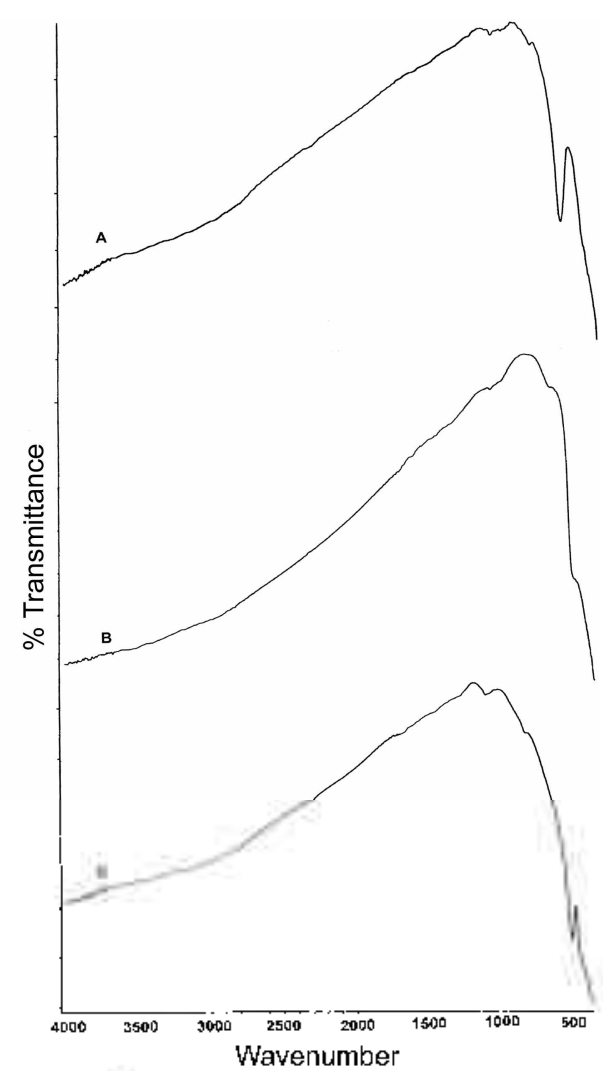

Fig. 5. The final decomposition products of: $(A):$ [Ta(hip) $\left.)_{i}\right]$ $4 \mathrm{I}_{2} \mathrm{O},\left([3):\left[\mathrm{Co}(\mathrm{hip})_{3}\right] \cdot 7 \mathrm{I}_{2} \mathrm{O}(\mathrm{C}):\left[\operatorname{Sm}(\mathrm{hip})_{3}\right] \cdot 8 \mathrm{H}_{2} \mathrm{O}\right.$.

Toble 3. Thermal data of the decomposition reactions of Lat(III), Ce(III) and Sm(III) hippurates

\begin{tabular}{|c|c|c|c|c|c|}
\hline \multirow{2}{*}{ Compounds } & \multirow{2}{*}{ Iecomposition } & \multirow{2}{*}{$\mathrm{T}_{\mathrm{Tux}} \mathrm{CO}$} & \multirow{2}{*}{ J.osispucies } & \multicolumn{2}{|c|}{ \%weight losses } \\
\hline & & & & Found & Calc. \\
\hline \multirow{4}{*}{ 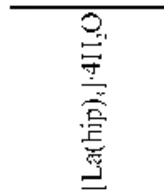 } & First stage & $89^{\circ} \mathrm{C}$ & 4180 & $9.11 \%$ & $9.66 \%$ \\
\hline & Second stage & $290^{\circ} \mathrm{C}$ & $10 \mathrm{C}_{2} \mathrm{Il}_{2}-\mathrm{NI} \mathrm{I}_{3}-5 \mathrm{CO}+\mathrm{Il}_{2} \mathrm{O}+2 \mathrm{NO}$ & $65.74 \%$ & $65.23 \%$ \\
\hline & Iotal loss & & & $74.85 \%$ & $74.89 \%$ \\
\hline & Residue & & & $25.16 \%$ & $25.10 \%$ \\
\hline \multirow{4}{*}{ 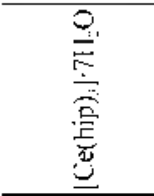 } & First stage & $119^{\circ} \mathrm{C}$ & $411 \leq$ & $9.12 \%$ & $9.00 \%$ \\
\hline & Second stage & $435^{\circ} \mathrm{C}$ & $\mathrm{IOC}_{2} \mathrm{H}_{2}-\mathrm{NI} \mathrm{I}_{3}-7 \mathrm{CO}-3.5 \mathrm{II}_{2} \mathrm{O}+\mathrm{N}_{2}$ & $71.22 \%$ & $70.50 \%$ \\
\hline & Tolal loss & & & $80.34 \%$ & $79.50 \%$ \\
\hline & Residue & & & $19.66 \%$ & $20.50 \%$ \\
\hline \multirow{4}{*}{ 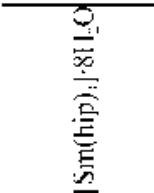 } & First stage & $78^{\circ} \mathrm{C}$ & $3 \mathrm{I}_{2} \mathrm{O}$ & $6.22 \%$ & $6.52 \%$ \\
\hline & second slage & $202{ }^{\circ} \mathrm{C}$ & $5 \mathrm{C}_{2} \mathrm{II}_{2}+\mathrm{NH}_{3}+\mathrm{CO}_{2}+\mathrm{N}_{2}+10.5 \mathrm{II}_{2} \mathrm{O}$ & $49.77 \%$ & $49.27 \%$ \\
\hline & Total loss & $378 \mathrm{"C}$ & & $55.99 \%$ & $55.79 \%$ \\
\hline & Residue & $540 " \mathrm{C}$ & & $4.01 \%$ & $44.20 \%$ \\
\hline
\end{tabular}

2005 . 


$$
10 \mathrm{C}_{2} \mathrm{II}_{2}+\mathrm{NII}_{3}+7 \mathrm{CO}+3.5 \mathrm{H}_{2} \mathrm{O}+\mathrm{N}_{2}+\mathrm{CeO}_{1.5}
$$

iii) $[\mathrm{Sm} \text { (hip) }]_{3} \cdot 8 \mathrm{II}_{2} \mathrm{O} \stackrel{75 \mathrm{C}}{\longrightarrow}\left[\mathrm{Sm}(\text { hip) })_{3}\right] \cdot 5 \mathrm{II}_{2} \mathrm{O}+3 \mathrm{H}_{2} \mathrm{O}$

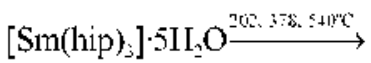

$$
\begin{aligned}
& 5 \mathrm{C}_{2} \mathrm{H}_{2}+\mathrm{NH}_{3}+\mathrm{CO}_{2}+\mathrm{N}_{2}+10.5 \mathrm{II}_{2} \mathrm{O}+16 \mathrm{C}+\mathrm{SmO}_{1.5}
\end{aligned}
$$

\section{REFINANCES}

1. Duboff, G. S.: Zarafonetis, C. J. D., Res. Conmunt. Chem. Pathol. Phamacol. 1978, 20,585.

2. Wan, S. H.; legelman, S. R, J. Pharm. Sci. 1972, 61, 1284.

3. Sinchowitz, L.; Daris, A. O., J. Gen. Plysiol. 1989, $49,95$.

4. Turner, R. W.; Charles, .V. G.; Amma, E. L., Cost. Shrtct. Conmum. 1982, $11,241$.

5. Micera, G: Valdini, L.: Erre, L. S.; Zoroddu, M. A.; Cariati, F., Inorg. Chim. Acta. 1985, 97, 183.

6. Inomata, I.: Moriwaki, T., Bull. Chem. Soc. Jpn. 1973, 46,1148
7. Sgarabotto, P.; Bisceglie, F.; Pelosi, Gi; Abdel-Raliaman, L., Poly-Hedron, 1999, 18, 2505.

8. Capllonch, M. C.; Garcia-Raso, A.; Terron, A.; Apella, M. C.; Espinosa, E.; Molins, E., J. Inorg. Biochem. 2001, 85(2-3), 173.

9. Monica, S.; Ledi, M.; Erika, F.; Deniela, I., J. Chent. Sor: Dalten trans., 2001, 9, 1513.

10. Sowney, S. S.; Alkakibli, Them. Chim. Acta, 1982. 56217.

11. Sadeek, S. A.: Refat, M. S.: Teleb, S. M.: El-Megharbel, S. M., J. Molecular Snicture In press 2004.

12. Sawhney, S. S.: Matta, S. D., Thernt. Chint Acta, 1981, $5], 363$.

13. Manhas, B. S.: Trikna, A. K., J. Indian chem. Soc., $1983,59,315$.

14. Nakiamoto, K., "Infrared and Raman spectra of Inorganic and coordination compounds," $4^{\text {th }}$ Edition, wiley, New York, 1986.

15. Kumar, G: Srivastava, M., Rer: Chint. Mher., 1979, $36,14$.

16. Brzyska, W.; Hakim, M., J. Pol. Chem. 1992, 66, 413. 